\title{
Interconnection of Kristevan Semiotic Chora and Nature in By the Light of My Father's Smile
}

\section{Kamelia Talebian Sedehi}

Cml_talebian@yahoo.com

\author{
Rosli Talif \\ rosli@fbmk.upm.edu.my \\ Wan Roselezam Wan Yahya \\ roselezam@gmail.com \\ Hardev Kaur \\ Universiti Putra Malaysia \\ jshardev@yahoo.com
}

Doi:10.5901/mjss.2015.v6n3s2p490

\begin{abstract}
Julia Kristeva's semiotic chora is the stage before the child acquires language and expresses himself within language. The semiotic deals with the infant's desires and impulses while his body is connected to his mother's body. Therefore, all his needs are fulfilled within this site. After the child perceives that he is separate from his mother's body, he enters the symbolic realm of language and uses language to express himself and his needs. The child likes to be part of his mother's body, but it is not possible; therefore, by gendering the nature, he can be part of his mother's body again. The land is considered as Mother Nature and gives the opportunity to men and women to experience the semiotic chora again. In Alice Walker's By the Light of My Father's Smile, men perceive women's needs by looking at the moon as part of the nature. They do not use language to communicate women, but by looking at the moon they recognize women's bodily desires. The current article will indicate how the child is connected to his mother in the semiotic chora and his needs are fulfilled and how men and women are connected to nature as a mother figure and they perceive the sexual needs and attempt to fulfill them without using language and only by paying attention to signs in nature.
\end{abstract}

Keywords: semiotic chora, By the Light of My Father's Smile, desire, moon.

\section{Introduction}

Throughout history, human beings had innate affiliation with nature. They felt calm while they maintained contact with nature. They built their houses near rivers and cultivated the earth and felt at home with nature. In By the Light of My Father's Smile, Alice Walker created a new pagan tribe of Mundo, a mix of African and American Indians. The Mundo tribe cares about the nature and its effect on men. They respect nature and they know that they cannot be separated from it. First women's cyclical rhythm is connected to moon, as one part of nature, and then men perceive women's needs and desires through looking at the moon. Both men and women have lunar connection; therefore men perceive how to treat women and their needs through looking at the moon. This article will focus on Julia Kristeva's concept the semiotic chora then this concept will be applied to Alice Walker's By the Light of My Father's Smile.

\section{Semiotic Chora}

Kristeva borrows the term chora from Plato's Timaeus, but she modifies it according to her theory and believes that from this space "the semiotic drives arise" (Kriseva 1984, 35). In Plato's view, chora is womb or receptacle; however, Kristeva considers it as a rhythm (and calls this rhythm the semiotic) that precedes language. In fact, Kristeva calls bodily drives 
and impulses semiotic. These drives move through the body of the subject who is not yet constituted as stable and then the drives are arranged based on social and cultural constraints (Kristeva 1984, 25). Kristeva sometimes refers to chora as semiotic chora because the chora is a site "from which the semiotic bursts forth" (Stokes-king, 2006, 61). In Plato's theory, chora is a space, in which the universe comes to existence. He explains how the universe was created, and in Kristeva's theory, chora is a site for the infant's relation to his mother's body and this kind of identification with the mother's body is one of the aspects of the semiotic. As the child has tactile relation with his mother's body, the child's drives are oriented in a constructive way. However, these drives are destructive by themselves; a child's tactile relation to his mother's body leads them to a normal path. In the chora, their sexual drives are directed by the mother's body (Kristeva 1984, 27). Besides, "the kinetic functional stage of semiotic precedes the establishment of the sign" (Rivkin and Ryan, 2000, 454). Kristeva considers chora as a "non expressive totality formed by the drives and their stases in a motility that is as full of movement as it is regulated" and this motility precedes generating the meaning and the signifying practice (Kristeva 1984, 25).

Its vocal and gestural organization is subject to what we shall call an objective ordering, which is dictated by natural or socio-historical constraints such as the biological difference between the sexes or family structure. (Kristeva 1984, 27)

At first, the child uses gestures and sounds to express himself, but he is not aware that these utterances have their own distinctive meaning. Later on, the child realizes that not only can he use language to indicate objects but also he realizes that he is separate from other people and his surroundings. Kristeva calls this stage the thetic break (1984, 43). It is the first step to understand the independent subjectivity through which the symbolic language which "posits discourse between subject and object comes into being" (Stokes-king, 2006, 37). Through the thetic break, the child enters the social world, social norms and symbolic realm. In fact, "the thetic is the precondition for both enunciation and denotation" (Kristeva 1984, 53). In order to come to the symbolic realm, the child unconsciously represses the rhythmic drives. The more the child enters the symbolic, the more the subject represses the articulation of the spoken and written word.

Kristeva assumes the thetic phase as the stage in which the child becomes able to learn grammar, and syntax. In fact, the semiotic is a bridge to the symbolic. In the rhythmic space of the semiotic which has no thesis and no position," the signification is constituted (Kristeva 1984, 26). In other words, it is "a prerequisite for the development of the symbolic" (Stokes-king, 2006, 39). Now the symbolic stage is shaped. The symbolic stage refers to the use of syntax and semantics. One should notice that the symbolic and the semiotic aspects of language are not separable.

Kristeva differs from previous theoreticians and considers language as part of a dynamic signifying process. It means that not only bodily drives and impulses are expressed within language, but also through it, the subjects gain their identity. In other words, language is both the expressions of orderly meaning and the subject's energy and drives.

\section{Interrelation of the Semiotic and the Symbolic}

As mentioned before, in the chora, there were just rhythms and sounds, which are bodily sounds such as a pulse or heartbeat and gestures. Gradually, the child perceives that he is separate from his surroundings; therefore, he comes to use symbolic language. "The symbolic aspect of language is logical, simple and stripped of stylistic, rhythmic, and poetic ambiguities... the symbolic order is the man's world"; also the symbolic realm dominates and represses the bodily drives (Jones, 1984, 56). The symbolic has the elements of signification and contains structure. Kristeva considers the symbolic language as "the patriarchal social structure," and defines it as a language with two functions (Stokes-king, 2006, 36-37). On the one hand, it permits one to access the order, and on the other hand, it represses unconscious thoughts. One should notice that "the semiotic phase becomes crucial to the signifying process within which no signifying operations could be realized" (Kristeva 1984, 58).

The symbolic- and therefore syntax and all linguistic categories are a social effect of the relation to the others established through the objective constraints of biological differences and concrete, historical family structures. (Kristeva 1984, 29)

On the other hand, semiotic is marked by "rhythm, intonation, gestures" (Jones 56). "Voice, gesture, colors, phonic, kinetic, or chromatic units and differences are the marks of these stases in the drives" that Kristeva considers as the semiotic (Kristeva 1984, 28). One can trace the semiotic in word play, semantics, "rhythmic, melodic or intonational structures," song, baby talk, echolalia, alliteration, onomatopoeia, portmanteau and colors even in dreams that originate from unconscious (Feral, 1976, 12).

Although these drives are the meaningful parts of language, they do not have any signification. In other words, 
these drives are like a language but they are not ordered yet. "The semiotic resists organization and it is very chaotic, while Kristeva links the symbolic to rational world" (Sutcliffe, 2003, 337). As Kristeva relates the symbolic to patriarchal social structure, she also considers the semiotic as maternal. The semiotic emotional expressions emerge unconsciously and without the speaker's will. Although "we shall distinguish the semiotic (drives and their articulation) from the realm of signification....in other words, a realm of proposition," the semiotic and the symbolic are interrelated even after the thetic break (Kristeva 1984, 43). They have dialectic of mutual contradiction; this dialect produces the normal language. The two aspects of language are so interdependent that "without the symbolic we have only a delirium, while without the semiotic, language would be completely empty if not impossible" (Groden and Kreiswirth, 1997, 2).

As Kristeva's psychological and linguistic concepts are concerned, one can notice the reason behind land- aswoman. The semiotic stage of language is before the child adopts the symbolic stage of language. The semiotic aspect of language deals with the unconscious and child's desires and emotion. In the semiotic state, the child connects himself with his surroundings. The mother's body, child's body and the whole environment are linked together and this state is called as semiotic chora by Julia Kristeva. As the child acquires language, he enters the symbolic but the traces of the semiotic will stay with him. The chora will be replaced by the symbolic realm of language. As the child enters the symbolic realm of language, he distinguishes difference between himself and his surroundings. However, the symbolic is always under the influence of both the semiotic and the symbolic (Kristeva, 1984, 24).

As the child's first place was his mother's embrace, then the child likes to be part of the mother's body again, but this time by gendering the nature as woman as "every space is the place of the mother" (Oliver, 1983, 36). The first environment that the child faces is the mother's body which is the semiotic chora. Therefore, the land is feminized as the subject intends to reexperince the semiotic chora. He intends to return back to the semiotic stage through projecting his desires to the environment; therefore, he feels harmony with nature and he can possess the nature. This study intends to focus on the use of nature- as - mother in order to indicate return of the man to nature to grasp those moments of semiotic chora that once he experienced during his infancy.

Besides, as Mundo people, in this novel, and nature are interconnected, one can trace ecocriticism in this novel as well. As ecocriticsm deals with the connection of man and nature By the Light of My Father's Smile can be considered as its good example. Ecocriticism started around 1990s and it relates literature and the environment" (Glotfelty, 1996, xviii). By connecting literature and environment, ecocriticism emphasizes the importance of paying attention to nature and preserving it. As Buell published his book The Environmental Imagination (1995) which was followed by Cheryl Glotfelty and Harold Fromm's The Ecocriticism Reader (1996) as well as many other works on the issue of nature and environment, the scholarly works on nature come into existence. In fact, ecocrticism is a theory by itself which emphasizes the nature and its relation to human being; moreover, it relates nature to literary works which also highlights the relation of man and nature. As nature and man can influence one another, the study of nature can give us an understanding about humans as well.

\section{Analysis}

Alice Walker's By the Light of My Father's Smile did not receive the same attention that her previous novels did. There was no significant scholarly work on it and the reviews were harsh toward it. However, By the Light of My Father's Smile is precious in its own existence as it discusses different subject matters, especially the violence against women. Though the novel is set in Mexico and mid $20^{\text {th }}$ century, one can apply the events which happen in it to different places and eras. Besides the violence towards women, other themes such as love, sexuality and nature are also emphasized in this novel. With an interview with Evelyn C. White, Walker notes that "sexuality is the place where life has fallen into the pit for women. The only way we ever change that is by affirming, celebrating and acknowledging sexuality in daily lives" (Walker, 2005, 45).

In her novel, Walker emphasized the way the Mundo people consider sex as a ritualistic act which is related to the nature and especially the phases of the moon, through which men and nature are united. Through looking at moon's phases, Mundo people perceive the appropriate time to have sex and become pregnant. With nature both men and women are united as both of them can connect to it. They are connected to moon's cycles and phases as well. When the moon is like smiling face, men perceive that women's ovulation is ended and she is ready to make love. As a result, Mundo men know the suitable time to make love and reproduce.

The Mundo tribe learned how women and nature, especially moon, are related to one another. As a result, through looking at moon, they perceive the next step they should take in their interaction with women. "How woman is connected to it and shares its rhythms. That a woman's tides, her blood tides, connect with the moon. That this is how women know in their bodies that they are a part of everything, even something so distant as the moon" (Walker, 2005, 210). The 
women's sexual needs and functions are related to the moon. As a result, men perceived that "when the moon releases and begins to wane, that is when they release their blood... during this time, a man may not make love to a woman. She feels somewhat irritable, somewhat messy, though she does not mind, since she and the moon are sharing, as they say, a big moment" (Walker, 2005, 211). The bodily organs are related to semiotic motility and here the woman's sexual organ is related to moon. Women are part of the nature and their emotions are directed toward it as the child's desires are channeled by his mother's body. There is link between women and nature vs. child and mother. Both women and child are connected to their mother's body and they feel they are one and not two separate beings. There is no otherness, but they are One being. This state is the semiotic chora in which the primary pleasures of the body dominate and there is no need to use language. The desires are fulfilled without asking.

As women have their period and the moon is dark and wane, men are helpless, but when the men lose hope, suddenly moon appears smiling which indicates women's willingness to have sexual relationship with men. Here, no word is said, but men perceive women's feelings through nature and smile, smile and gestures are considered as semiotic by Kriteva. As men can perceive the signification of each movement of moon, they are part of the nature as well. Men perceive women's desires through looking at moon as semiotic is inevitably linked with the female body" then the nature and semiotic aspect are related as well (Kriteva, 1984, 142). "Crescent moon, which is sometimes like a bowl or a boat, is the moon smiling its on the good lovemaking that is to come! The moon, while forever a woman, for just a little while becomes, also, a man" (Walker, 2005, 212). Men and women are unified in nature as they can connect one another by looking at the moon and perceive the meaning of its shape. Men become part of the nature and they can experience reunion with semiotic chora that once they experienced in their mother's embrace. However, this time instead of biological mother, men experience their impulses and desires in the presence of mother nature. They can make love to women without asking them to have sex. Through looking at moon, they perceive women's state of mind and their mood, therefore, their gestures prove their willingness to have sex or not.

\section{Conclusion}

All in all, the infant has relation with his mother's body within the chora. The chora is a rhythm which precedes language. It constitutes the infants desires and impulses before he gains his stable identity. The infant's needs are fulfilled in the chora without asking them. In Walker's By the Light of My Father's Smile, women's bodily rhythms and their blood tides are related to the moon and nature acts like a mother who fulfills her child's needs, without she asks them; therefore, by looking at the moon, men perceive the correct moment to have sex with women and satisfy both their and women's needs. They recognize the correct moment through looking at the moon and its different shapes.

\section{References}

Féral, Josette, Julia Kristeva, and Penny Kritzman. (1976). "China, Women and the Symbolic An Interview with Julia Kristeva." SubStance 5.13. : 9-18.

Glotfelty, Cheryll. (1996). "Introduction." The Ecocriticism Reader: Lndmarks in Literary Ecology. Ed. Cheryll Glotfelty and Harold Fromm. Athens $U$ of Georgia P.

Groden, Michael, and Martin Kreiswirth. (1997). The Johns Hopkins Guide to Literary Theory and Criticism. USA: Johns Hopkins University Press.

Jones, Ann, R. (1984). "Julia Kristeva on Femininity: The Limits of a Semiotic Politics." Feminist Review 18. : 56-73.

Kristeva, Julia. (1984). Revolution in poetic Language. Trans. Margaret Waller. New York: Columbia University Press.

Oliver, Kelly. (1993). Reading Kristeva: Unraveling the Double- bind. Bloomington: Indiana University Press.

Otsuka, Rena. (2008). "Subject in process": Modernist characterization in Virginia Woolf's "Mrs. Dalloway" and "To the Lighthouse". Diss. California State University, Dominguez Hills. Dissertations \& Theses: Full Text, ProQuest. Web. 6 Aug. 2011.

Rivkin, Julie, and Michael Ryan. (2000). Literary Theory: An Anthology. New York: Blackwell Publisher.

Stokes-King, Lisa. (2006). "Lovely shapes and sounds intelligible": Kristevan semiotic and Coleridge's language of the unconscious. Diss. McGill University (Canada). Dissertations \& Theses: Full Text, ProQuest. Web. 6 Aug. 2011.

Sutcliffe, Benjamin M. (2003). "Reading the Kristevan Semiotic and Symbolic: Nina Sadur's "Kol'tsa" and Marina Kulakova's "Rekapoimeni Master". " Canadian Slavonic Papers 45.3/4 : 337. Academic Research Library, ProQuest.Web. 6 Aug. 2011.

Thurschwell, Pamela. (2000). Sigmund Freud. Kentucky: Routledge, 2000.

Walker, Alice. (2005). By the Light of My Father's Smile. London: Phoenix Paperback, 2005.

---.(1998). "Alice Walker on Finding Your Bliss." Interview by Evelyn C. White. Ms. Sept- Oct. 42- 50. 